\title{
Computer-assisted cognitive rehabilitation with and without unihemispheric concurrent dual-site a-tDCS and conventional tDCS on improving the response inhibition in patients with stroke
}

\author{
Milad Amini Masouleh" ${ }^{1}$, Gholamreza Chalabianloo ${ }^{2}$, Reza Abdi $^{2}$ \\ 1-M.A Cognitive Sciences, Psychology Department, Azarbaijan Shahid Madani University, Tabriz, Iran. \\ 2- Associate Professor, Psychology Department, Azarbaijan Shahid Madani University, Tabriz, Iran. \\ Corresponding Author: Gholamreza Chalabianloo E-mail: chalabianloo@azaruniv.ac.ir \\ Received: 03/10/2020 Accepted: 23/12/2020
}

\begin{abstract}
Introduction: The response disinhibition is one of the most common problems in post-stroke patients. Many studies have shown that transcranial direct current stimulation could improve cognitive impairments by increasing the cortical excitability.

Aim: The present study was performed to investigate the effect of two protocols of direct transcranial electrical stimulation with cognitive rehabilitation in patients with stroke.

Method: The research method was quasi-experimental with a control group. From the population of stroke patients in 2016, 32 people (including 21 men and 11 women aged 40 to 65 years) were selected by purposive sampling method based on including and excluding criteria. All subjects in the study groups underwent Fruit Ninja task training as cognitive rehabilitation and transcranial direct current stimulation and were evaluated by continuous performance, flanker and target stop tasks. Findings were analyzed using repeated measures analysis of variance with SPSS-22.

Results: The results showed that the group that receiving stimulation with unihemispheric concurrent dual-site a-tDCS along with computerized cognitive rehabilitation in comparison to groups with unihemispheric tDCS with \& without computerized cognitive rehabilitation \& sham stimulation, showed a significant improvement in response inhibition function $(\mathrm{P} \leq 0.05)$. Also, at 8-weeks follow-up, the unihemispheric concurrent dual-site a-tDCS along with computerized cognitive rehabilitation group continued to show better functions in response inhibition tasks than other groups $(\mathrm{P} \leq 0.05)$.
\end{abstract}

Conclusion: The present results show that the simultaneous use of transcranial stimulation along with cognitive rehabilitation has an effective role in improving cognitive deficits.

Keywords: Rehabilitation, Transcranial direct current stimulation, Inhibition, Stroke

How to cite this article : Amini Masouleh M, Chalabianloo Gh, Abdi R. Computer-assisted cognitive rehabilitation with and without unihemispheric concurrent dual-site a-tDCS and conventional tDCS on improving the response inhibition in patients with stroke. Shenakht Journal of Psychology and Psychiatry. 2021; 7 (6): 12-27 .URL: http://shenakht.muk.ac.ir/article-1-725-en.pdf

Copyright $\odot 2018$ the Author (s). Published by Kurdistan University of Medical Sciences. This is an open access article distributed under the terms of the Creative Commons Attribution-Non Commercial License 4.0 (CCBY-NC), where it is permissible to download, share, remix, transform, and buildup the work provided it is properly cited. The work cannot be used commercially without permission from the journal. 


\title{
توانبخشى شناختى رايانهاى باو بدون تحريك الكتريكى مستقيم فرا جمجمهاى همز مان دو موضعى تك نيمكر هاى بر بهبودى بازدارى باسخ در بيماران مبتلا به سكته مغزى بهاي
}

\author{
ميلاد امينى ماسوله '، غلامر ضا جلبيانلو ‘، رضا عبدى \\ ا.كارشناس ارشد علوم شناختى، گرووه روانشناسى، دانشگاه شهيد مدنى آذربايجان، تبريز، ايران.

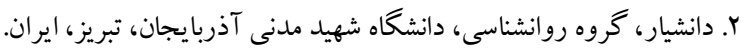 \\ ايميل:azaruniv.ac.ir \\ مولف مسئول: غلامرضا جلبيانلو
}

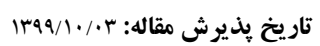

ثاريخ دريافت مقاله:

جكيده

مقدمه: نقص بازدارى ياسخ يكى از شايع ترين مشكلات بيماران بعد از سكتههاى مغزى است. بسيارى از مطالعات نشان دادهاند كه

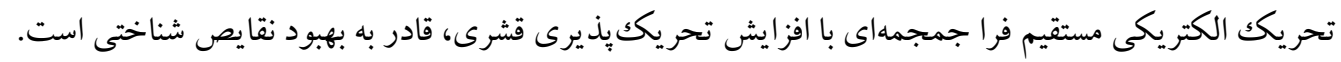
هدف: يزوهش حاضر به منظور بررسى تأثير دو بروتكل تحريكك الكتريكى مستقيم فرا جمجمهاى همراه با توانبخشى شناختى در بيماران مبتلا به سكته مغزى انجام شد.

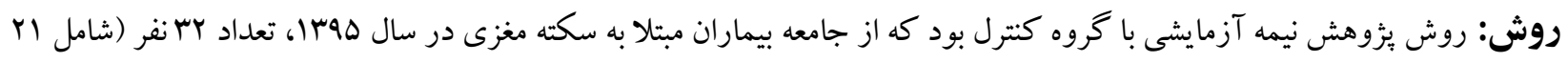

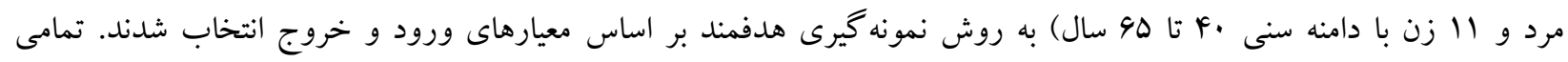
آزمودنىها در قالب گروههاى مورد مطالعه، تحت آموزش تكليف فروت نينجا به عنوان توانبخشى شناختى و تحريك الكتريكى

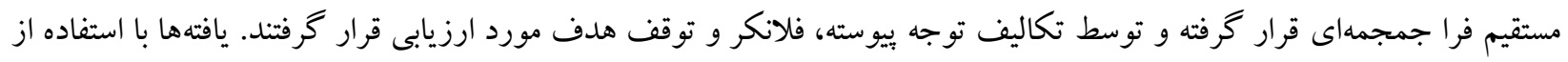

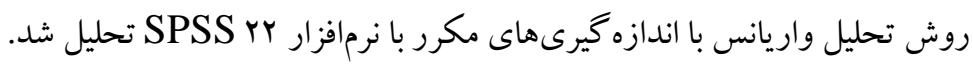

يافتهها: نتايج نشان داد كه گروه توانبخشى شناختى توأم با تحريكك فرا جمجمهاى دو موضعى در مقايسه با ساير گروهها بهبود

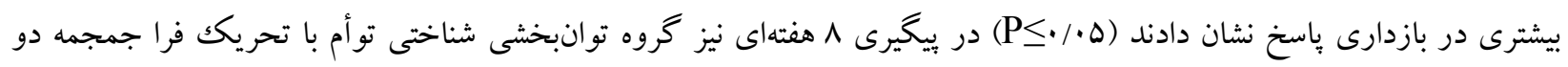

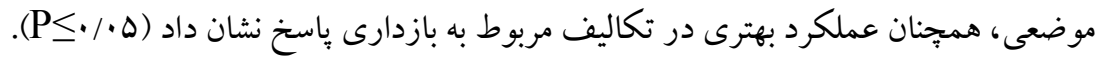

نتيجه كيرى: نتايج حاضر نشان مىدهند كه استفاده همزمان از تحريك الكتريكى به همراه توانبخشى شناختى، نقش مؤثرى در بهبود نقايص شناختى دارد. كليدوازهها: توانبخشى شناختى رايانهاى، تحريك الكتريكى مستقيم فرا جمجمهاى، بازدارى ياسخ، سكته مغزى 
جلو گيرى از ياسخهاى رفتارى نامرتبط تعريف مى كنند

كه باعث بروز رفتارهاى معطوف به هدف و منعطف

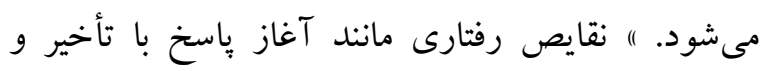
نقص در بازدارى از ياسخ مىتوانند همراه با يكديخر و يا

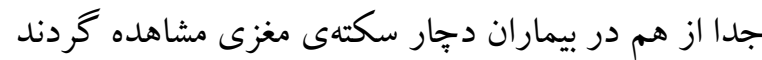
(ويسى بير كوهى، حسنى ابهريان، كاظمى، واثقى، زرين

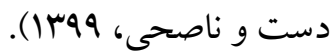

از ميان تكنيككهاى مختلفى كه در برنامه هاى توانبخشى شناختى جنين بيمارانى به كار مىرود، توانبخشىهاى

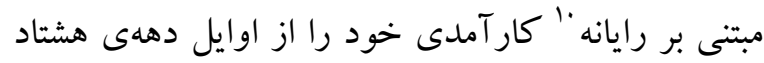
ميلادى در بهبود نواقص شناختى سالمندان و ساير بيماران دجار صدمات مغزى، دمانس و يا اسكيزوفرنى، نشان دادهاند (حسنزاده، زارع، علييور و شريف الحسينى،

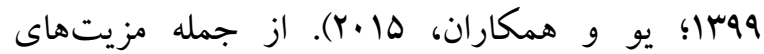
بهره گيرى از جنين تكنيككهايى، مقرون به صرفه بودن و فراهم كردن شرايط درمان برحسب نيمرخ عصب روانشناختى هر يكك از بيماران به صورت مستقل است. از طرف ديخر، ئزوهشهاى اخير نشان دادهاند، هنگامى ئى كه تحريك الكتريكى مستقيم فرا جمجمهاى" همراه با هرئ روشهاى تمرينى استاندارد و يا بروتكل هاى توانبخشى به كار مىرود؛ اثربخشى آنها به ميزان قابل توجهى در

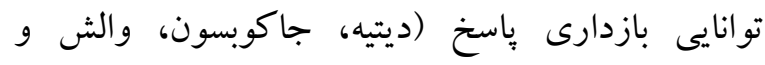

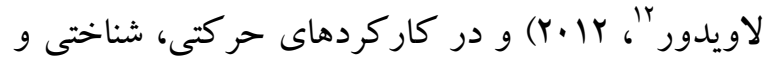

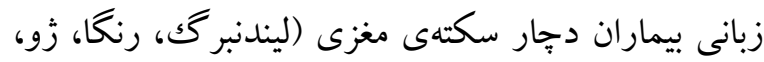

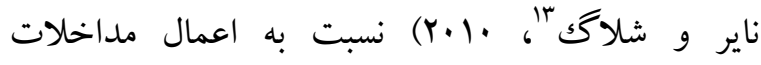
توانبخشى به تنهايى، افزايش مىيابد.

${ }^{10}$ - Computer-Based Cognitive Rehabilitation (CBCR)

${ }^{11}$ - Transcranial direct current stimulation (tDCS)

${ }^{12}$ - Ditye, Jacobson, Walsh \& Lavidor

${ }^{13}$ - Lindenberg, Renga, Zhu, Nair \& Schlaug
كاركردهاى اجرايى اشاره به مجموعه عملكردهايى

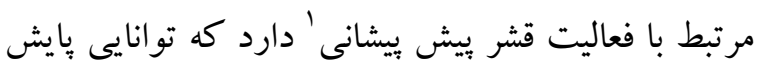
و تعديل رفتار در حال وقوع را در موقعيتهاى شناختى، هيجانى و اجتماعى گوناگون فراهم مىسازد كه شامل طيف وسيعى از كاركردهاى عالى شناختى و فراشناختى

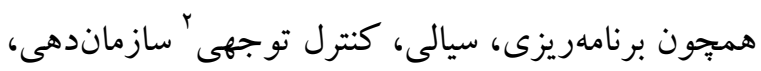

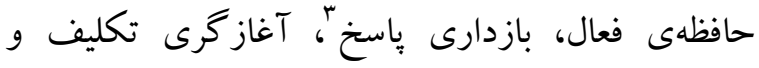

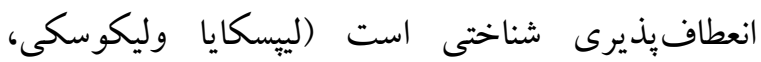

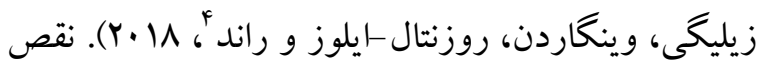
در جنين كاركردهايى از علائم رايج در بسيارى از اختلالات مغزى همجِون بيمارىهاى مرتبط با اضمحلال نورونى هو سكته مغزى است كه مشكلات فراوانى را در كاركردهايى همجِون تمركز، حافظه و حل مسئله ايجاد

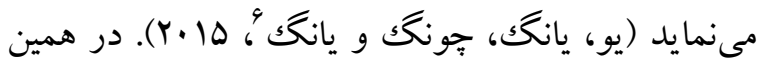
راستا، نيمرخ عصب روانشناختى بيماران دجار سكتهى مغزى عمدتاً با ايجاد تغيير در كاركردهاى اجرايى مانند بازدارى پياسخ همراه با نقص در حافظهى كلامى، بخصوص يس از سكتهى مغزى نيمكرهى راست است بـ بـ

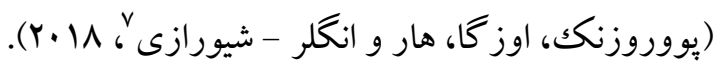
بازدارى بِاسخ اشاره به توانايى اداره و جهت بخشيدن به توجه با جشميوشى از اطلاعات نامرتبط و حفظ توجه بر محرك كي آيتم مربوطه، دارد (كوته، بونتيفكس، هيلمن و

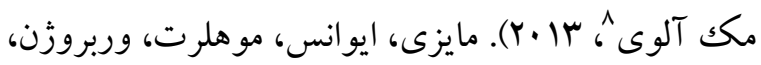

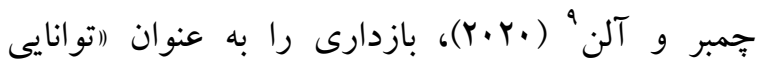

\footnotetext{
1. Prefrontal cortex

2 - Attentional control

${ }^{3}$ - Responses

4- Lipskaya-Velikovsky, Zeilig, Weingarden, Rozental-Iluz \& Rand

5 - Neurodegenerative

${ }^{6}$ - Yoo, Yong, Chung \& Yang

7. Povroznik, Ozga,Haar \& Engler-Chiurazzi

${ }^{8}$ - Gothe, Pontifex, Hillman \& McAuley

${ }^{9}$ - Maizey,Evans,Muhlert,Verbruggen,Chambers \& Allen
} 
توجه بيوستهى شنيدارى و ديدارى بيماران دجار سكتهى مغزى مورد بررسى قرار داده و نشان دادند كه بهبود معنادارى در عملكرد بيماران در مقايسه با گروه كنترل صورت گرفته بود. مطالعات اخير تصويربردارى تشديد مغناطيسى كاركردى نشان داده است كه تحريك آنودال در تحريك الكتريكى مستقيم فرا جمجمهاى موجب

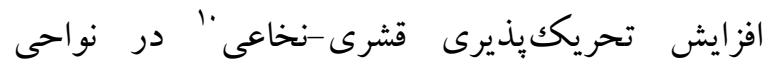
موضعى محل تحريك و همجنين مناطق دورتر مى گردد (هوللا، بيسوالا، رامشا،شيواكومارا، بارات، بنگالا،

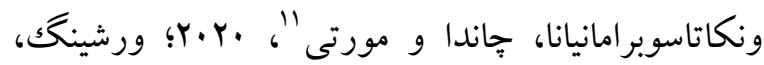

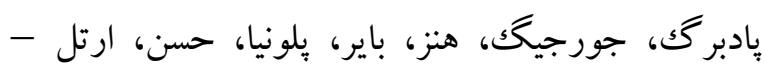

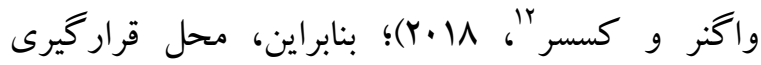
الكترود مى تواند اثرى معنادار در توزيع فضايى و مسير جريان الكتريكى ايفا نمايند. در اغلب بثروهشهايى كه در آنها تحريك الكتريكى مستقيم فرا جمجمهاى مورد استفاده قرار كرفته است، از يك الكترود آنود و يكى الكترود كاتود بر روى بوست سر، استفاده شده است؛ اما از مونتازهاى ديكر همجون يك الكترود آنود و دو الكترود كاتود و با دو الكترود آنود و دو الكترود آنود نيز مورد استفاده قرار گرفته است (اوتز، دينوا، اوين لاندر و

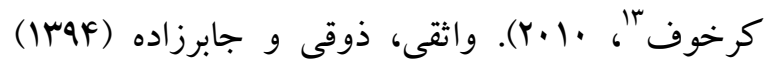
نشان دادند استفاده از تحريكك هم زمان كورتكس حركتى اوليه و نواحى كاركردى با القاى بيشتر

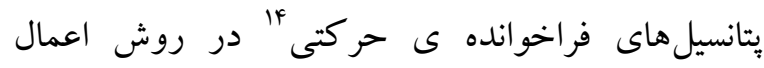
تحريك الكتريكى مستقيم فرا جمجمهاى آنودال به لهي

\footnotetext{
${ }^{10}$ - Corticospinal

11- Hollaa,Biswala,Ramesha,Shivakumara, Bharath, Benegala Venkatasubramaniana, Chanda \& Murthy

${ }^{12}$ - Worsching,Padberg, Goerigk, Heinz, Bauer, Plewnia, Hasan, Ertl-Wagner \& Keeser

${ }^{13}$ - Utz, Dimova, Oppenländer \& Kerkhoff

${ }^{14}$ - Motor-evoked potentials (MEPs)
}

كاربرد جنين بيروتكل توانبخشى محدود به كار كردهاى زيانى و حركتى نيست و مىتواند طيف وسيعى از كاركردهاى شناختى را در بر بـيرد. يثزوهشهاى انجام شده در جمعيتهاى بهنجار با به كارگيرى همزمان تحريكك الكتريكى مستقيم فرا جمجمهاى و توانبخشى شناختى در يكك جلسه، حاكى از اين بوده است كه استفاده از جنين : يروتكلى مىتواند عملكرد افراد در كاركردهاى شناختى همجيون حافظهى فعال، ياد گيرى را به مدت كوتاهى افزايش دهد (دراييسما، وسللا و هامل'، r.Y.r.

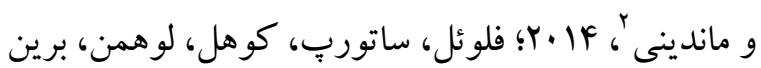

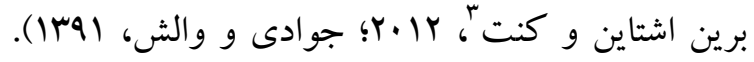
تحقيقات نشان دادهاند كه بازدارى يِاسخ با افزايش فعاليت در نواحى بشتى - ميانى كورتكس برى فرونتال؛

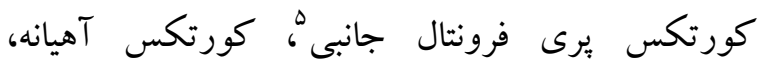

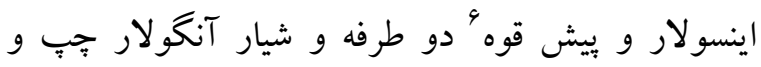

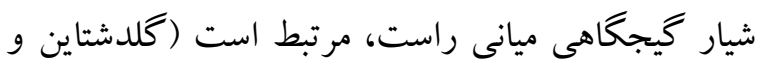

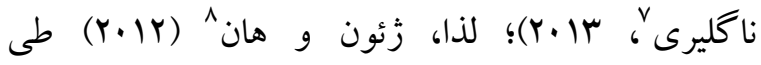
يثوهشى، با استفاده از تحريكك الكتريكى مستقيم فرا جمجمهاى، ناحيهى خلفى جانبى قشر بيش ييشانى جب را تحريكك نمودند كه باعث بهبود معنادار عملكرد در

$$
\text { تكليف استروبٍ گرديد. }
$$

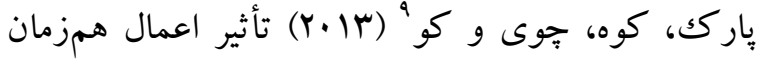
تكاليف كامييوترى شناختى و تحريك الكتريكى مستقيم فرا جمجمهاى را در مقايسه با گروه كنترل، بر عملكرد

\footnotetext{
- Draaisma, Wessela \& Hummel

2- Penolazzi, Bergamaschi, Pastore, Villani, Sartori and Mondini

3 - Floel,Suttorp, Kohl, Kurten, Lohmann, Breitenstein \& Knecht

4 - Dorsomedial prefrontal cortex

5 - Lateral prefrontal cortex

6 - Precuneus

7. Goldstein \& Naglieri

8 - Jeon \& Han

${ }^{9}$ - Park, Koh, Choi \& Ko
} 
شامل تمامى بيماران دجار سكتهى مغزى بودند كه در سال هوسا به بيمارستانهاى شهر رشت در استان خيلان مراجعه نمودند. از جامعه فوق نمونهاى به تعداد •F نفر به روش نمونه كيرى هدفمند بر اساس معيارهاى شمول و استثنا انتخاب شد. ملاككهاى شمول و استثنا در يزوهش حاضر به شرح زير بود: ملاككهاى ورود شامل راست دست، ردهى سنى ·F تا 9 9 سال، سبرى شدن ا تا ب ماه از سكته، بينايى و شنوايى طبيعى، حداقل تحصيلات دييلم، كسب حداقل نمرهى 11 در آزمون ارزيابى شناختى مونتر ال. ملاككهاى خروج شامل سابقهى ضربهى مغزى، اختلالات روانيز شكى، صرع و سوءمصرف مل الكل

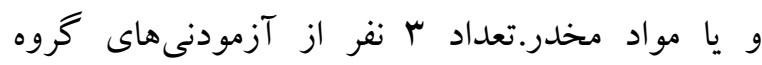
آزمايشى توانبخشى شناختى بدون اعمال تحريك الكتريكى مستقيم فرا جمجمهاى، ب نفر از گروه آزمايشى لرسى اعمال توانبخشى شناختى همراه با تحريك الكتريكى مستقيم فرا جمجمهاى، ب نفر از گروه آزمايشى اعمال توانبخشى شناختى همراه با تحريك الكتريكى مستقيم فرا جمجمهاى به صورت دو موضعى تكك نيمكرهاى و 1 نفر نيز از گروه كنترل در طول اجرا بثوهش به دلايلى

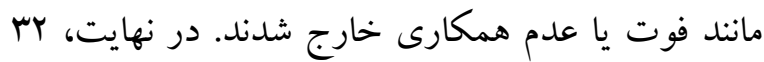
بيمار (ll زن و الب مرد) در بيزوهش شركت نمودند.

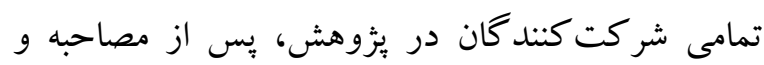
كسب اطلاع از فرايند مطالعه، فرم رضايتنامهى آكاهانه جهت حضور در بثزوهش را تكميل نمودند و نسبت به رازدارى و عدم افشاى اطلاعات به آنان اطمينان خاطر

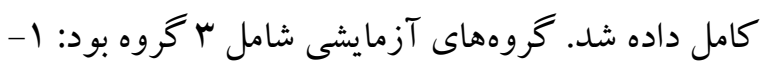
توانبخشى شناختى همراه با تحريك الكتريكى مستقيم

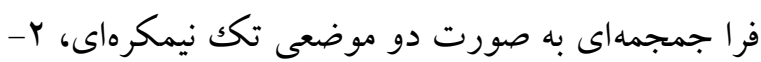
توانبخشى شناختى همراه با تحريك الكتريكى مستقيم
صورت دو موضعى همزمان يك نيمكرهاى، نسبت به روش مرسوم بود. در همين راستا، كو كلتا، دامبورسكا، رومن، ركتور و برازديل' (Y.19) نيز بر نقش كاركردى مستقيم ناحيهى حر كتى اوليه در فعاليتهاى مختلف شناختى، تأكيد نمونه و نشان دادند ناحيهى حركتى اوليه در سركوب باسخ به صورت ارادى و همجنين آمادگى حركتى بهواسطىى وجود مدارهاى برنامهريزى حر كتى، دخيل است (كن و

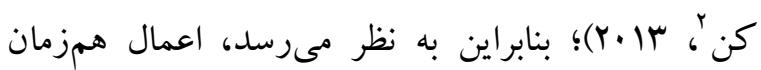
تحريكك آنودال در ناحيهى مربوطه و منطقهى كاركردى مرتبط به دليل تعاملات شبكهاى موجود در كاركردهاى بيجيدهى عصبى همجيون بازدارى پاسخ، مىتواند نقش مهمى در توسعه تكنيككهاى توانبخشى در كاركردهاى شناختى بيماران دجار سكتهى مغزى به دليل وجود ساختارهاى شبكهى در مغز ايفا نمايد. با اين وجود، سيها تاكنون تأثير جنين مونتازى بر بهبود كاركردهاى اجرايى سيى از جمله بازدارى ياسخ در جمعيتهاى بالينى همجون

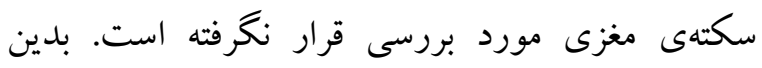
منظور، يُوهش حاضر با هدف طرح اين سؤال كه آيا استفاده از يروتكل توانبخشى شناختى مبتى بر تكاليف كامييوترى با و بدون تحريكك الكتريكى مستقيم فرا

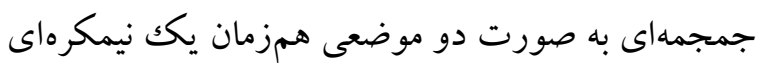

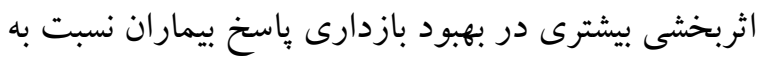
روش هاى مرسوم دارد و يا خير، انجام مى يذيرد.

\section{روش} روش يزوهش حاضر، طرح نيمه آزمايشى از نوع بيش و

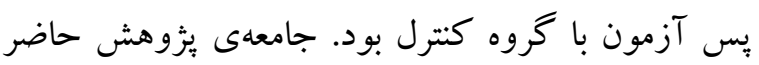

\footnotetext{
1- Kukleta, Damborská, Roman, Rektor \& Brázdil

${ }^{2}$ - Kwon \& Kwon
} 
ارزيابىهاى مورد نظر، مورد بررسى قرار گرفتند. هشت

هفته يّ از اتمام مداخله، آزمودنىها به طور مجدد بهوسيلهى ابزارهاى يادشده، براى تعيين ميزان اثربخشى يروتكلهاى استفاده شده مورد ارزيابى قرار كرفتئد. خلاصه گرووبندىها و مداخلات صورت كرفته درد جدول ا ارائه شده است.
فرا جمجمهاى به صورت تكك موضعى ب- توانبخشى شناختى بدون تحريك الكتريكى مستقيم فرا جمجمهاى. شركت كنندكان، ه مرتبه در هفته و به مدت f م هفته، تمرينات توانبخشى شناختى به مدت ·ـ دقيقه (هر يكك از تكاليف به مدت ها دقيقه) و تحريك الكتريكى مستقيم فرا جمجمهاى را دريافت نمودند. يّس از اتمام دورهى مداخله، آزمودنىها به طور مجدد بلهوسيلهى

\section{جدول ا خلاصه طرح يثوهشى اجرا شده (كروه بندى ها و مداخلات انجام شده)}

\begin{tabular}{|c|c|c|c|c|}
\hline محل كاتد & محل آند & يروتكل مداخله & تعداد جلسات & كروه \\
\hline سوير الربيتال نيمكرهى & 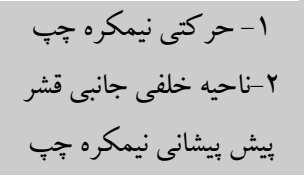 & 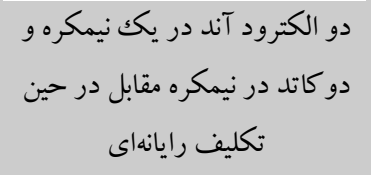 & 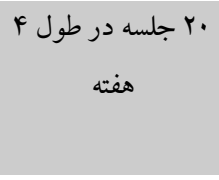 & تحوانبخشى شناختى توأم با الكتر يكى فراجمجمه \\
\hline سوير |اربيتال نيمكرهى & 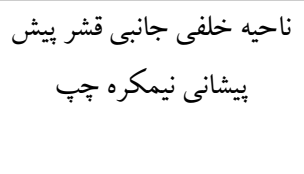 & $\begin{array}{c}\text { يكك الكترود آند در يكك نيمكره و اتد در نيمكره مقابل در حين } \\
\text { يكام تكليف رايانهاى }\end{array}$ & 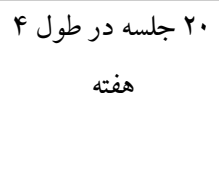 & توانبخشى شناختى توأم با تحرى الكتريكى فرا فـ تكى موضعى \\
\hline - & - & $\begin{array}{c}\text { تنها اجراى تكليف رايانهاى بدون } \\
\text { تحريك فرا جمجمهاى }\end{array}$ & 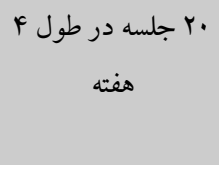 & $\begin{array}{c}\text { توانبخشى شناختى بدون الكتريكى فرا } \\
\text { تمجمهاى }\end{array}$ \\
\hline سوير الربيتال نيمكرهى & 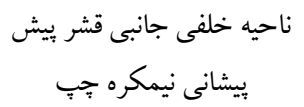 & دستكاه يِ از ·ب ثانيه خاموش مى شد & 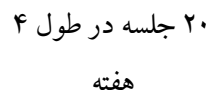 & تحريك كاذب (شم) \\
\hline
\end{tabular}

آنود بر روى نواحى حركتى نيمكره جٍِ و ناحيه خلفى

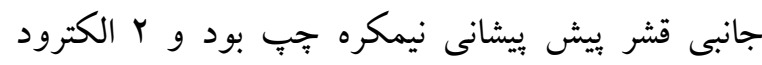
كاتد بر ناحيهى سوبراربيتال نيمكرهى مقابل (راست) كار گذارى شد (واثقى و همكاران، آزمايشى ديخر، تحريك از طريق يك الكترود آند بر

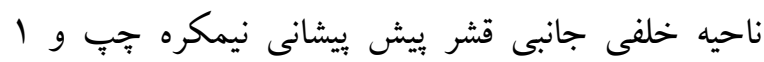
الكترود كاتد در ناحيهى سوير|اربيتال نيمكرهى مقابل (راست) اعمال شد. گروه كنترل نيز تحريك را به مدت لهرئ • ب ثانيه دريافت نمودند و سبس دستخاه به صورت خود كار قطع شد. تحريك الكتريكى مستقيم فرا جمجمهاح: در يزوهش

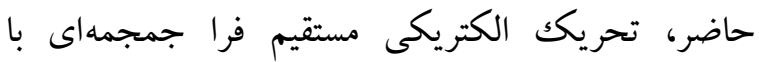

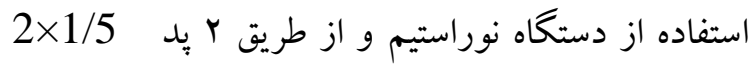

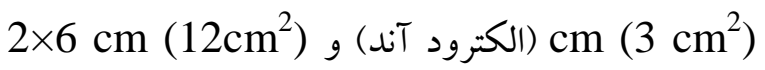
(الكترود كاتد) آغشته به محلول نمك به شدت جربان r/• ميلى آمبر و به صورت مستقيم به مدت •ب دقيقه و در حين اجراى تكاليف شناختى كامييوترى (آنلاين) اعمال

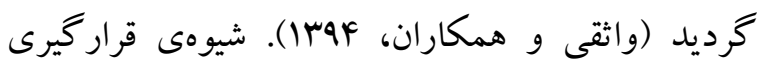
الكترودها در گروه همراه با تحريك آنودال دو موضعى همزمان يكك نيمكرهاى به اين صورت بود كه ب الكترود 
آزمون عملكرد بيوسته: جهت ارزيابى توجه بِيدار و بازدارى آزمودنىها از نسخهى رايانهاى آزمون عملكرد بيوسته كه توسط نرمافزار زبان آموزسازى روانى بّارائه شده است، استفاده شد. در طول اجراى اين تكليف، مجموعهاى از حروف بر روى صفحهى كاميوتر ارائه مى گردد و آزمودنى مىبايست به تمامى حروف، جز لز حرف X با فشار دادن كليد مربوطه در صفحه كليد واكنش نشان دهد. در مجموع .4M محرك در طى 11 بلوكى (در هر بلوكى ·r حرف) در فواصل ............

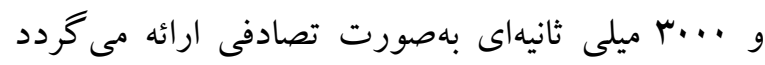
(مولر، ·(Y.1). دو متغير خطاى ارتكاب و خطاى هدف كه توسط تكليف به صورت خود كار محاسبه مى گردد، به عنوان نمرهى آزمودنى در اين تكليف لحاظ

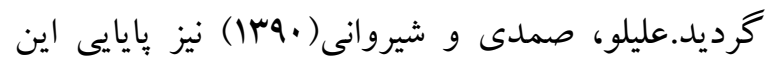
آزمون را |ه/ • گزارش كردند. روايى آزمون نيز در حد مطلوبى گزارش شد. تكليف توقف هدف؛؛ جهت ارزيابى توانايى بازدارى آزمودنىها از تكليف توقف هدف (ورنبروگن، لو گان و لواني

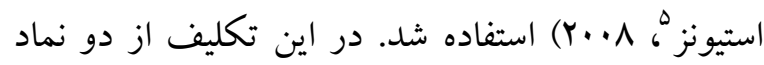
دايره و مربع در هر مرتبهى آزمون استفاده شده است. سايز محركك هاى ديدارى برابر با هإئ سانتىمتر مربع است كه به مدت •l/YD ميلىثانيه بر روى صفحه باقى مىماند. آزمودنىها مىبايست در سريع ترين زمان ممكن

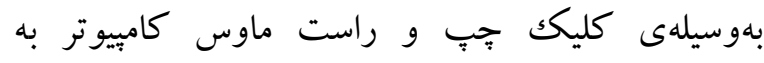
محر ككها ياسخ دهند. بدين صورت كه به محرك كايره

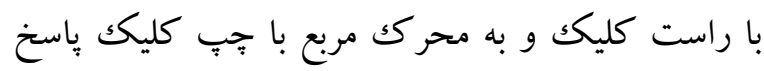

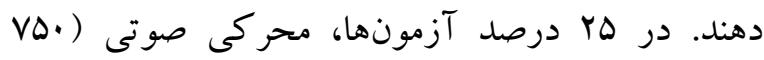
هرتز - VD ميلى ثانيه) اندكى بس از محرك ديدارى ارائه

${ }^{3}$ - The psychology experiment building language(PEBL)

4. STOP-IT

5- Verbruggen, Logan \& Stevens
آزمون ارزيابع شناختى مونترال ': براى بررسى وضعيت شناختى بيماران از آزمون ارزيابى شناختى مونترال

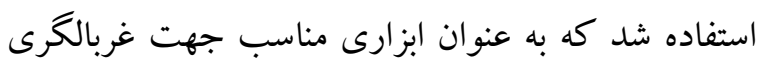
براى اختلالات شناختى خفيف به شمار مىرود. اين آزمون با هدف برطرف كردن نواقص آزمون كوتاه وضعيت ذذنى توسط نصرالدين، فيلييس، بدريان،

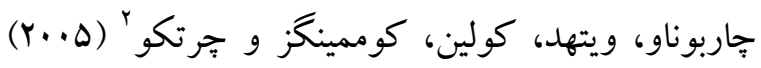
ساخته شده است كه حوزههاى شناختى بيشترى را نسبت به آزمون ياد شده ارزيابى مىنمايد. اين آزمون 1 كاركرد شناختى را در ·r سؤ ال كه شامل حافظهى كوتاه مدت، مهارتهاى ديدارى-فضايى، كاركردهاى اجرايى، تمركز، حافظهى فعال، زبان و آكاهى نسبت به زمان و مكانهاى مختلف است را مورد سنجش قرار مىدهد. حداكثر نمره قابل اكتساب در اين آزمون ·r است كه

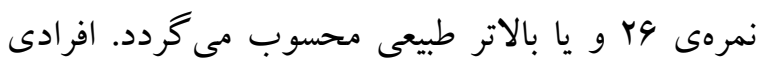
كه كمتر از Y I سال سابقهى تحصيل دارند، 1 نمره به

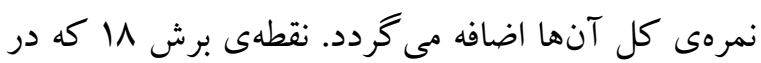
اين يُزوهش لحاظ شد، حداقل شرايط شناختى لازم جهت شركت در يُوهش است. پايايى اوليه آزمون با آزمون آلفاى كرونباخ سه/، گزارش شده است

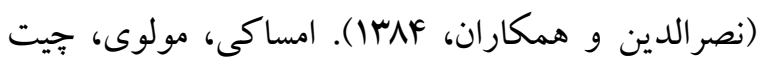
ساز، موحد و عسكرى (·وسו) در زيزوهشى به مطالعهى

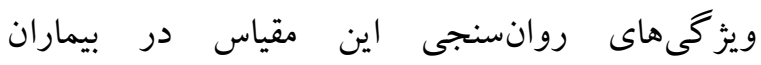
ياركينسونى شهر اصفهان يرداختند. ضريب آلفاى

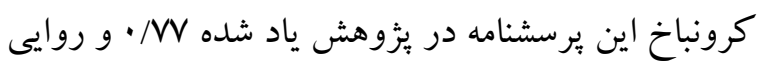
همزمان آن برابر با V9/ • گز ارش شد.

\footnotetext{
1. Montreal Cognitive Assessment Test (MCOA)

${ }^{2}$ - Nasreddine, Phillips, Bédirian, Charbonneau, Whitehead, Collin, Cummings \& Chertkow
} 
متجانس و يا محر ككهاى خنثى احاطه شده است. در اين

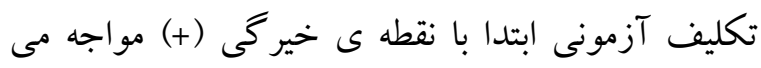

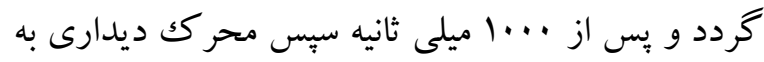

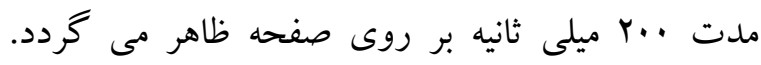
تكليف آزمودنى تشخيص جهت بيكان ميانى و عدم توجه به بيكان هاى احاطه كننده در سريع ترين زمان ممكن با استفاده از كليد هاى كيبرد (Z) و (/) به ترتيب براى جهت هاى جֶٍ و راست مى باشد. اريكسن و اريكسن (19VF) پايايى و روايى اين تكليف را در حد مطلوب و قابل قبولى گز ارش نموده اند. بازى تجارى فروت نينجا: به منظور توانبخشى بازدارى

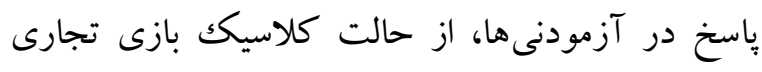

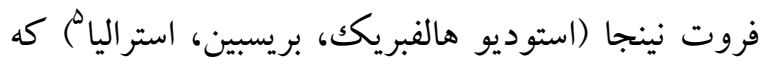
توانايى شناختى بازدارى از پِاسخ آزمودنى را درگير مى سازد، استفاده شد. اين بازى دو نوع محرك كي (ميوه و يا بمب) را به صورت تصادفى ارائه مى كند. آزمودنى ها مى بـ بايست تنها به ميوه ها بِاسخ دهند (ياسخ به محرك كَ) و از

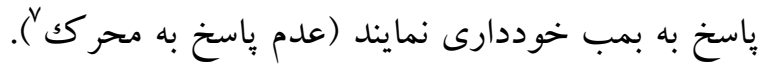

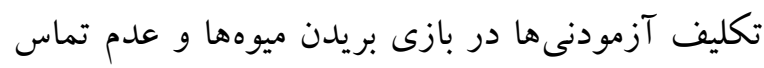
با بمبها خو اهد بود. هنگامى كه به محر كك ميوه توسط آزمودنى بريده مىشود، به عنوان يكك امتياز مثبت براى او

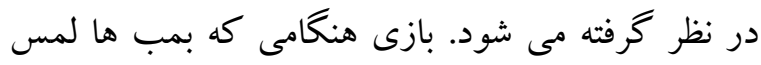
شوند و يا بيش از سه محرك ميوه از دست بروند، تمام خواهد شد. امتياز هر مرتبهى بازى ثبت خرديد و امتياز نهايى آزمودنى حاصل ميانگين سه مرتبه از بالاترين امتيازهاى به دست آمده بود. آزمودنى اين بازى را به مدت ها دقيقه در هر جلسهى توانبخشى اجرا خواهد كرد. ئزوهش ليو، زو، زيخلر و شى (Y.19) نشان داد،

5 - Halfbrick Studios, Brisbane, Australia

6. Go-stimuli

7- No go stimuli
مى گردد كه هنگام شنيدن آن آزمودنى مىبايست بلافاصله از ياسخ دادن خوددارى نمايد (توقف علامت'). زمان بين ارائه محركك و توقف علامت در هر آزمون تنظيم شده است (تأخير در توقف علامت r). تكليف با تأخير در توقف علامت حدود ·لم ميلى ثانيه آغاز مى شود و به دنبال آن يس از يِاسخ درست، زمان تأخير در توقف علامت، ·له ميلىثانيه افزايش مىيابد. بس از ياسخ نادرست، زمان تأخير در توقف علامت، ·ه ميلى ثانيه كاهش مىيابد. تكليف شامل r مرحله است كه مرحلهى نخست از r T آزمون تمرينى و مرحلهى دوم از 194

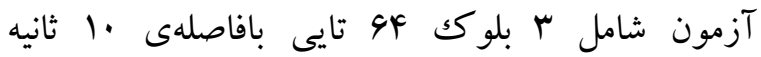
استراحت ميان بلوككها تشكيل يافته است (ورنبرو

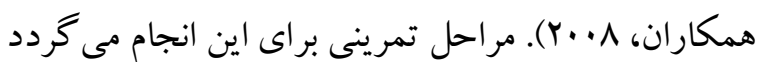
تا آزمونخر نسبت به فهم آزمودنىها از شرايط تكليف

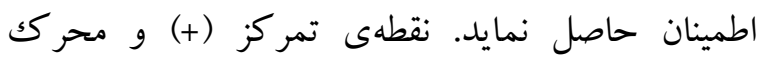
ديدارى در وسط صفحهى نمايشخر با رنخك سفيد در زمينهى سياه ارائه مى گردد. ورنبرو گن و و همكاران (Y.人) قابل قبولى گز ارش نموده اند. تكليف فلانكرّ" به جهت ارزيابى كنترل بازدارى آزمودنىها، از نسخهى كامييوترى تكليف فلانكر در نرمافزار زبانآموز سازى روانى استفاده شد. نسخهى استاندارد اين تكليف توسط اريكسن و اريكسن (19VF) معرفى شد. اين تكليف از ^ نوع آرايه مختلف از يبكانهاى سفيد و محر ككهاى خنثى در بسزمينهى سياه با جهت جِ و و يا راست تشكيل شده است كه توسط حداكثر f بيكان ديكر به صورت متجانس و يا غير

\footnotetext{
1- Stop Signal

${ }^{2}$ - Stop Signal Delay(SSD)

3 - Flanker

${ }^{4}$ - Eriksen and Eriksen
} 
كاذب (شم) • D هF/VN

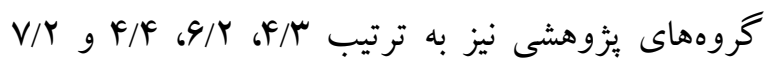

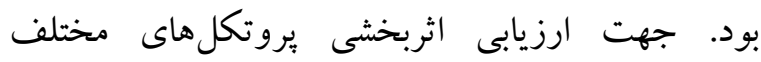
توانبخشى بر بِاسخ بازدارى مشاهده شده در تكليف

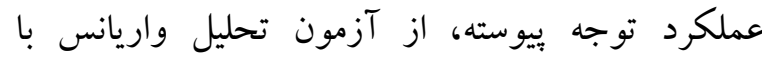
اندازهيرىهاى مكرر استفاده شد. در اين تكليف دو نوع خطا شامل خطاهاى حذف و ارتكاب مورد بررسى واقع مىشوند. نتايج اين تحليل در جدول شماره Y نشان داده شده است.
استفاده از اين بازى مىتواند در بهبود كنترل بازدارى و فعاليت عصبى مؤثر باشد.

\section{يافته ها}

ميانگين و انحراف معيار سنى براى گروه توانبخشى شناختى توأم با تحريكك الكتريكى فرا جمجمهاى دو

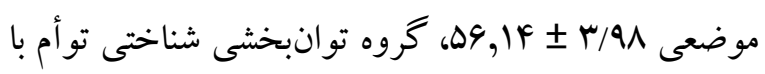

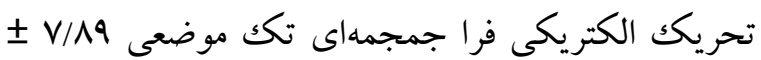
هV فرا جمجمهاى D/FF

\begin{tabular}{|c|c|c|c|c|c|c|c|}
\hline مجذور & معنىدارى & $\mathbf{F}$ & مجذانكين & درادى درجه & مجذوروات مجموع & عامل ع & \\
\hline . AVY & $\cdot / \cdot .1$ & $r \Delta / \cdot \cdot$ & VQA/roq & r & IOA9/VIr & خطاى حذف & درون كروهى \\
\hline$\cdot /$ TAF &.$/ \cdot 1$ & r/TOF & $1 \cdot V / 1 .$. & 9 & GKY/G.r & خطاى حذف & \\
\hline.$/ 10 \Delta$ & NS & $1 / V I F$ & $\mid 999 / \cdot 11$ & $r$ & $\mid F \cdot V / T F r$ & 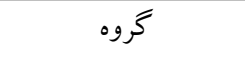 & بين كروهى \\
\hline.$/ 09 V$ &.$/ \cdot 1$ & FI/FAT & IFY/NHY & r & $r \wedge \Delta / 49 D$ & خطاى ارتكاب & درون كروهى \\
\hline - /FFD &.$/ \cdot 1$ & V/Far & ro/WVq & 9 & $1 \Delta F / G V Y$ & خطاى ارتكابق كروه & \\
\hline$\cdot / F \Delta A$ &.$/ \cdot .1$ & V/AqT & $\mid \Delta r / \cdots 1$ & $r$ & $F \Delta Q / \cdot Y F$ & كروه & بين كروهى \\
\hline
\end{tabular}

مستقيم فرا جمجمهاى آنودال به صورت تكك موضعى

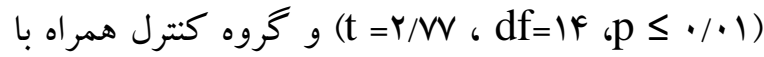
تحريك تصنعى (t است. همجنين تفاوت ميانگين گرووه توانبخشى شناختى با تكاليف رايانهاى همراه با اعمال تحريك الكتريكى مستقيم فرا جمجمهاى آنودال به صورت تكك موضعى و

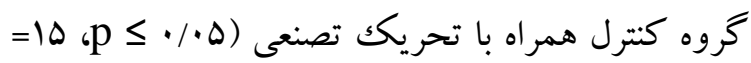
(t = =يز معنادار است. در مرحلهى بيگيرى نيز df df

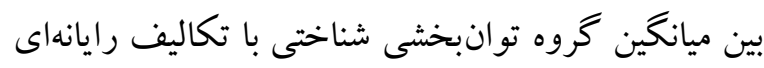
همراه با اعمال تحريكك الكتريكى مستقيم فرا جمجمهاى آنودال به صورت دو موضعى همزمان يكك نيمكرهاى با بأ
نتايج جدول شماره Y نشان مى دهد كه در خطاى ارتكاب از آزمون عملكرد بيوسته بين گرووهاى مورد

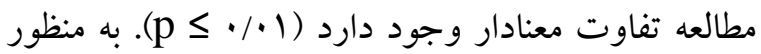
مقايسه ميانگين گرووه ها از آزمون t استفاده شد. نتايج

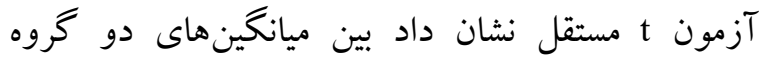
توانبخشى شناختى با تكاليف كامييوترى همر اه با اعمال تحريكك الكتريكى مستقيم فرا جمجمهاى آنودال به صورت دو موضعى همزمان يكك نيمكرهاى با گروه توانبخشى شناختى با تكاليف رايانهاى، (1 ( p

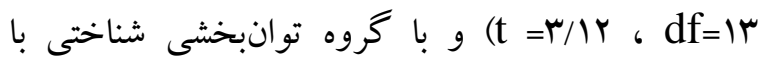
تكاليف رايانهاى همراه با اعمال تحريك الكتريكى 


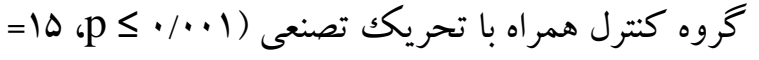

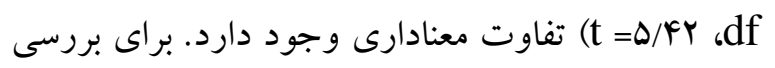
عملكرد شركت كنند كان در آزمون توقف هدف نيز از

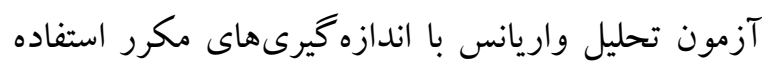

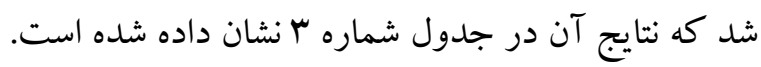

كروه توانبخشى شناختى بدون اعمال تحريك الكتريكى مستقيم فرا جمجمهاى و (t

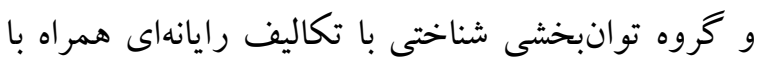

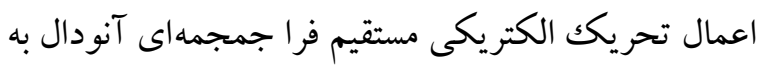
صورت تكك موضعى (t

جدول r نتايج آزمون تحليل واريانس براى بررسى اثربخشى يروتكلهاى توانبخشى بر تكليف توقف هدف

\begin{tabular}{|c|c|c|c|c|c|c|c|}
\hline مجذور & معنىدارى & $\mathbf{F}$ & مجذذورات & آزادى & مجذورات & عامل & \\
\hline - / FAr & $\cdot / \cdot 1$ & $r r / \cdot v r$ & rYTN/919 & 4 & $\begin{array}{l}\text { GFVV/YHA } \\
V A \cdot 1 / 9 \cdot 9\end{array}$ & 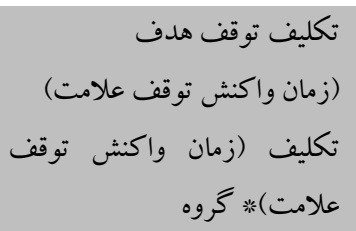 & درون كروهى \\
\hline$\cdot / 499$ & $\%$ & $\Delta /$ Taq & $949 \Delta / 19 Y$ & r & 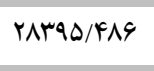 & كروه & بين كروهى \\
\hline 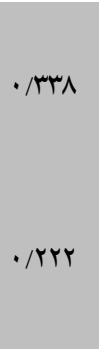 &.$/ \cdot 1$ & $\mid F / r \cdot r$ & rAGTO/IT. & r & Q1TD./YG. & 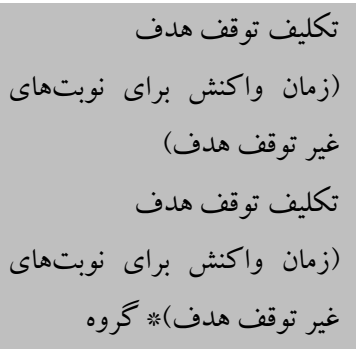 & درون تروهى \\
\hline - / YAT & .1 .0 & $r / 9 V Y$ & FAFAN/.99 & $r$ & $\mid F \Delta F G F / Y \cdot \Lambda$ & كروه & بين كروهى \\
\hline
\end{tabular}

اعمال تحريك الكتريكى مستقيم فرا جمجمهاى آنودال به صورت دو موضعى همزمان يك نيمكرهاى و گروه توانبخشى شناختى با تكاليف كامييوترى همراه با اعمال

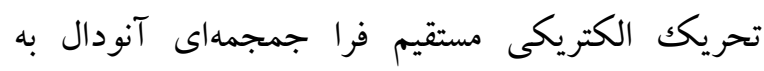
صورت تكك موضعى (t=

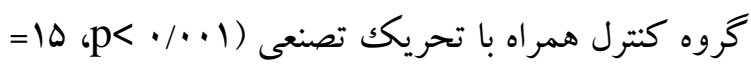
(t= F/lr،df

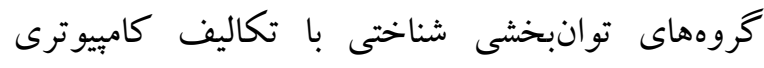

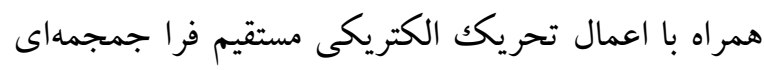

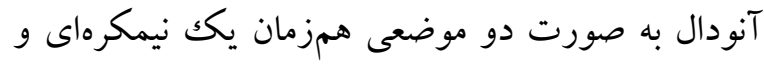

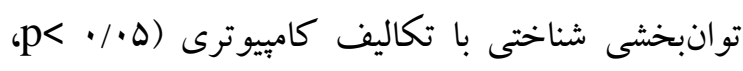

همانكونه كه در جدول شماره r مشاهده مىشود، خلاصهى تحليل واريانس بيانكر آن است كه اثر اصلى نمرات اكتسابى آزمودنىها در تكليف توقف هدف

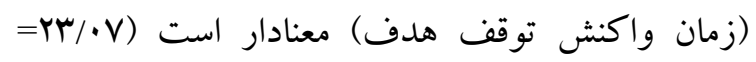

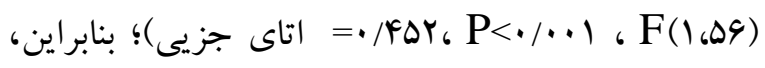

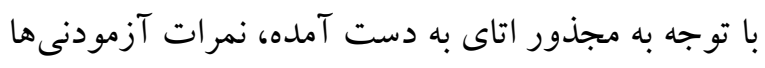

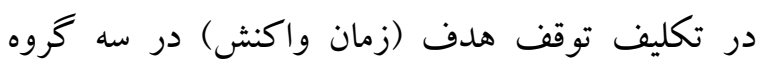
آزمايشى و گروه كنترل تفاوت معنادارى با يكديغر

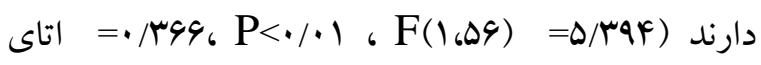
جزيى). نتايج آزمون t مستقل نيز نشان داد تفاوت بين

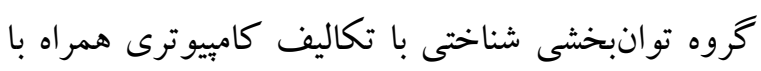




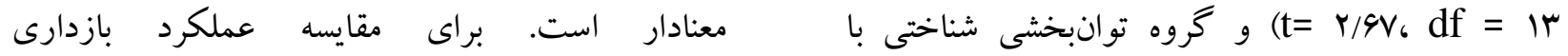
تكاليف كامييوترى همراه با اعمال تحريك الكتريكى شركت كنند كان در تكليف فلانكر نيز از تحليل واريانس با اندازهيرىهاى مكرر استفاده شد كه نتايج آن در مستقيم فرا جمجمهاى آنودال به صورت تكك موضعى جدول شماره F نشان داده شده است.

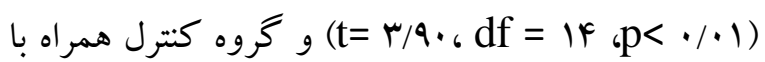
تحريكك تصنعى (t= (t)

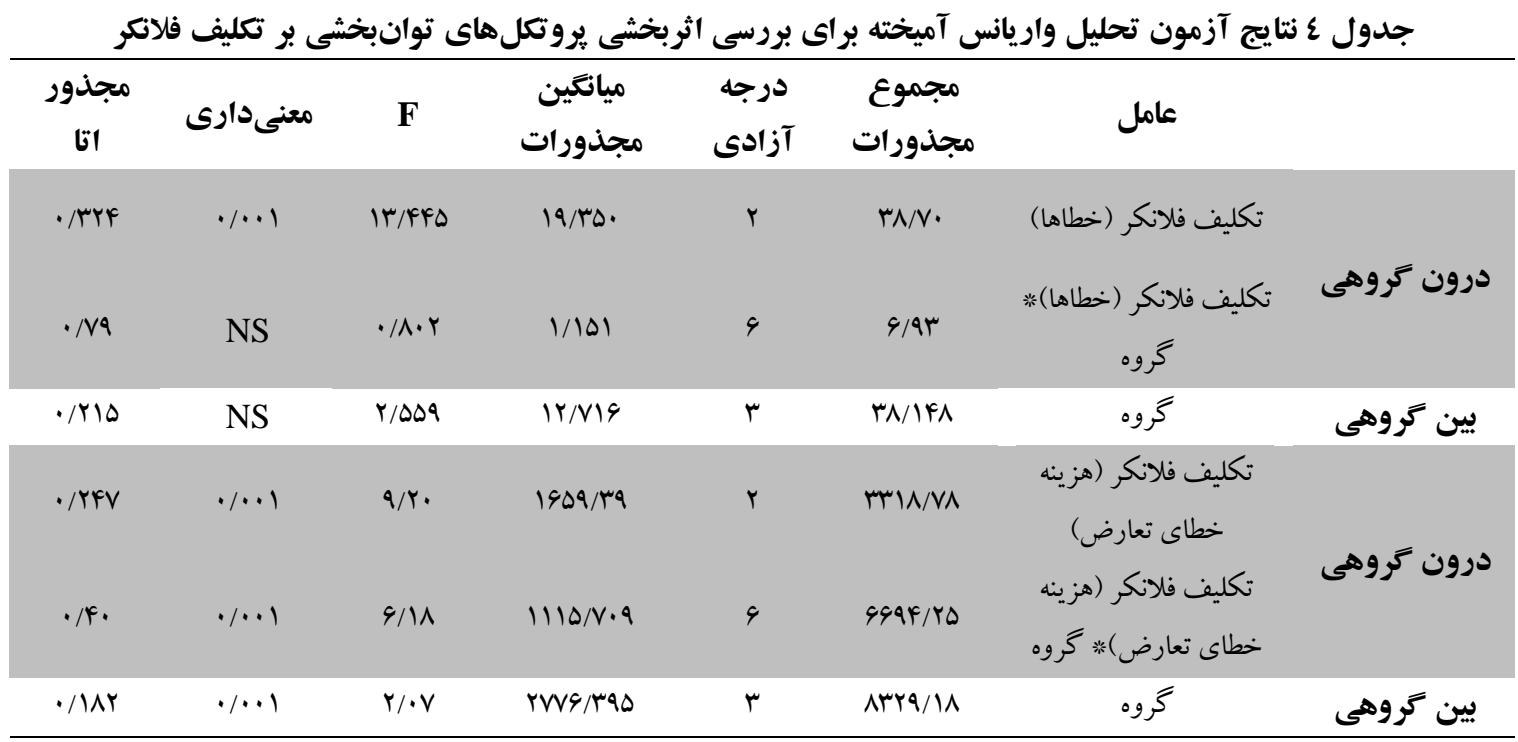

صورت دو موضعى همزمان يكك نيمكرهاى و كروه توانبخشى شناختى با تكاليف كامييوترى همراه با اعمال

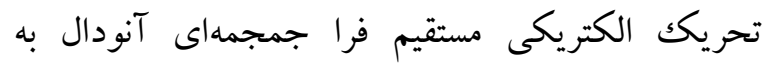

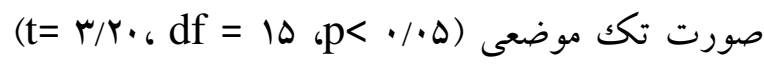
معنادار است. در بيگيرى نيز، بين ميانگينهاى گرووه توانبخشى شناختى با تكاليف كامييوترى همراه با اعمال

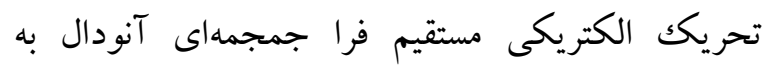

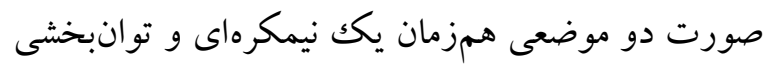
شناختى بدون اعمال تحريكك الكتريكى مستقيم فرا

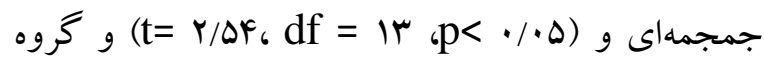
توانبخشى شناختى با تكاليف كامييوترى همراه با اعمال

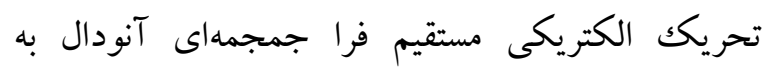

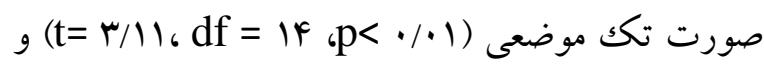

همان كونه كه در جدول شماره f مشاهده مىشود، خلاصهى تحليل واريانس بيانخر آن است كه اثر اصلى نمرات اكتسابى آزمودنىها در تكليف فلانكر در شاخص ميزان خطاها معنادار است (FF/FF

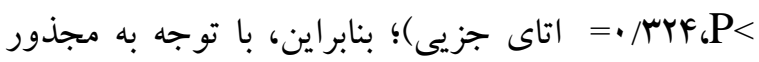
اتاى به دست آمده، نمرات آزمودنىها در تكليف فلانكر در شاخص ميزان خطاها در سه گروه آزمايشى و گروه

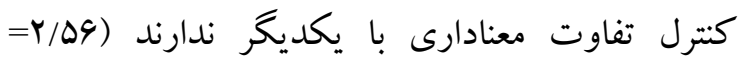

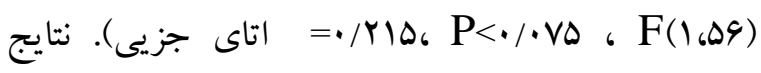
آزمون t مستقل با مقايسهى ميانگين نمرات تكليف فلانكر نشان مىدهد شاخص هزينهى تعارض بين كروه توانبخشى شناختى با تكاليف كامييوترى همر اه با اعمال

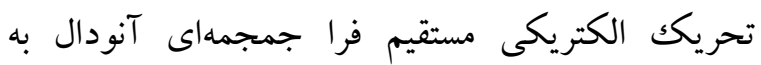




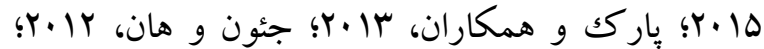

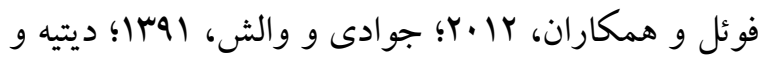

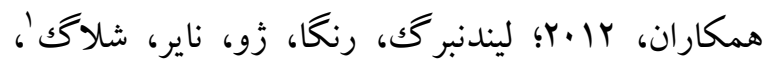
(Y.1). جمجمهاى مى تواند با افزايش ميزان تحريكريذيرى كورتكسى در شبكهاى مربوط به كاركردهاى اجرايى

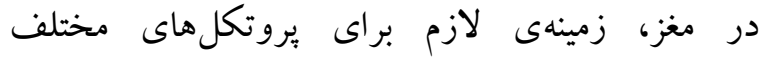
توانبخشى شناختى در بيماران دجار صدمات مغزى را فراهم مىسازد. از طرف ديخر ئزوهش حاضر نشان داد، تحريك آنودال همزمان نواحى دركير در يكك نيمكره، مىتواند منجر به افزايش اثربخشى يروتكلهاى

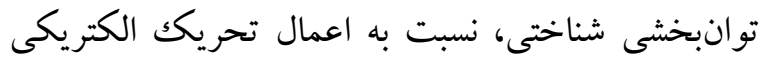
مستقيم فرا جمجمهاى بر روى ناحيهى قشر بيش بيشانى خلفى جانبى، در عملكرد افراد در كاركردهاى اجرايى مى گردد. اين يافتهها، با نتايج به دست آمده توسط واثقى و همكاران (FqM) كه نشان داد، تحريك همزمان ناحيهى كار كردى مرتبط در علاوه بر ناحيهى مورد نظر، موجب افزايش القاى بِتانسيل هاى فراخوانده ى حركتى در افر اد بهنجار مى گردد، همسو بود.

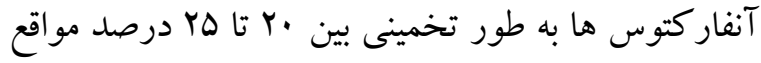
سبب ضايعاتى در ناحيه بيشانى مى گردد. علاوه بر اين، بيماران دجار سكتهى مغزى نواحى خلفى نيز، جيزى قريب به ·r درصد مواقع نواحى ييشانى را دجار آسيب

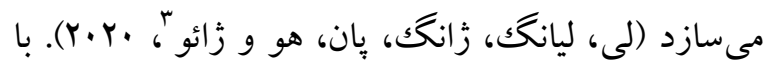
اين وجود، نرخ بالاى سكته هاى مغزى نواحى فرونتال به معناى آن نيست كه ضرورتاً نقص در كاركردهاى برى اجرايى تنها به دليل ضايعهاى ايجاد شده در نواحى

${ }^{1}$ - Lindenberg, Renga, Zhu, Nair \& Schlaug

${ }^{2}$ - Motor-evoked potentials (MEPs)

${ }^{3}$ - Li, Y.Liang, Zhang, Pan, Hu \& Zhao
كروه كنترل همر اه با تحريك تصنعى (ه+/. تفاوت معنادارى نشان داده شد. (t= Y/VF،df

״ذوهش حاضر با هدف مقايسهى بروتكلهاى توانبخشى شناختى مبتنى بر تكاليف كامبيوترى، با و

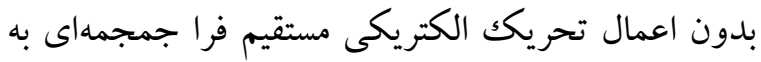
صورت دو موضعى تك نيمكرهاى بر روى نواحى حركتى اوليه و قشر بيش ويشانى خلفى جانبى و روش مرسوم (تحريكك قشر خلفى جانبى بيش بيشانى) انجام

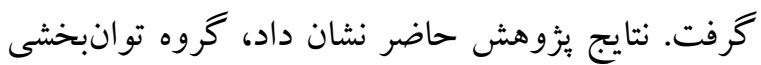
شناختى همراه با اعمال تحريك الكتريكى مستقيم فرا جمجمهاى به صورت دو موضعى نيمكرهاى بر روى نواحى حركتى اوليه و قشر بيش بيشانى خلفى جانبى، نسبت به گروه توانبخشى شناختى بدون اعمال تحريك الك

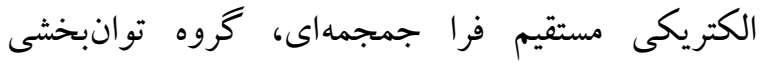
شناختى همراه با اعمال تحريك الكتريكى مستقيم فرا جمجمهاى بر روى ناحيهى بيش بيشانى خلفى جانبى و كروه كنترل، عملكرد بهتر و زمان واكنش كوتاهتر و صحت پياسخ بيشترى را در تكاليف مربوط به بازدارى باسخ شامل تكليف توجه بيوسته شاخص خطاى ارتكاب، تكليف فلانكر و تكليف توقف هدف در مراحل يس آزمون و همجنين مرحلهى بيڤيرى از خود نشان دادند. در درجهى نخست ئزوهش حاضر نشان داد، اجراى همزمان توانبخشى شناختى مبتنى بر تكاليف كامبيوترى

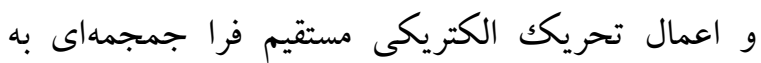
صورت آنلاين، اثربخشى بيشترى نسبت به اعمال توانبخشى شناختى رايانهاى به تنهايى دارد. اين نتايج با يافته هاى تحقيقات بيشين همسو بود (لئو و همكاران، 
كورتكس ناحيهى ييش حركتى به دو قسمت يشتى و

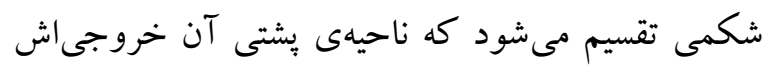
را به ناحيهى حركتى اوليه و طناب نخاعى مىفرستد و ورودى هايى از ناحيهى قشر بيش ويشانى خلفى جانبى دريافت مى كند. مدولاسيون يا تعديل مربوط به توجه در ناحيهى بيش بيشانى خلفى جانبى و دادههاى مربوط به آمادكى حركتى در ناحيهى بشتى كورتكس بيشى بيش حر كتى توسط ناحيهى حر كتى اوليه دريافت مى گردد. در نتيجهى جنين ساختار كاركردى، به نظر مىرسد كه

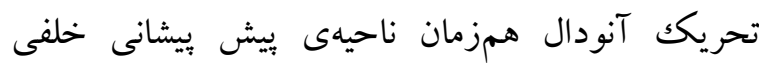
جانبى و حركتى اوليه مىتواند، منجر به فعالسازى مسير عصبى بيش بيشانى خلفى جانبى - به طرف قشر حركتى

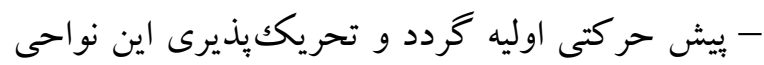
را افزايش دهد (واثقى و همكاران، عar|). به نظر مىرسد با توجه به وجود جنين مسيرهايى بين اين دو ناحيه، تحريكك دو ناحيه بهطور همزمان سبب فعالسازى بيشتر و در نتيجه بهبود در كاركردهاى مزبور به بازدارى ياسخ در بيماران دجار سكته ى مغزى گردد. از طرف

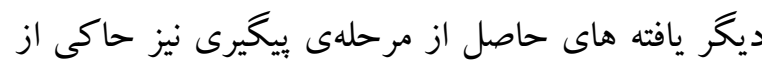

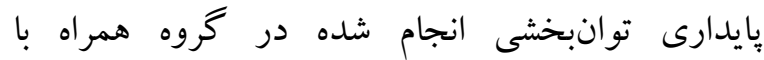

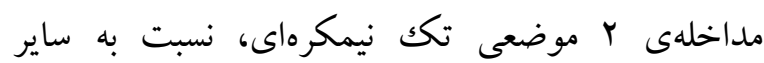

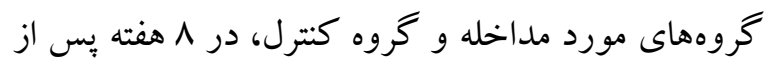

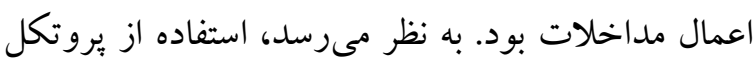
تحريك الكتريكى مستقيم فرا جمجمهاى همزمان موضعى تكك نيمكرهاى مىتواند اثربخشى تمرينات توانبخشى شناختى را افزايش داده و بهبود عملكرد بيماران دجار سكتهى مغزى را در تكاليف مربوط به بازدارى باسخ افزايش دهد.
فرونتال است؛ جِندين مطالعه (شايو' و همكاران، •r.r؛ هايس، دونلان و استو كس'، 19.r) نشان داده است كه سكتهى مغزى در نواحى خلفى و قدامى سبب ناتوانى و ضعف در اجراى آزمون هاى مربوط به كاركردهاى اجرايى مى كردد. به نظر مىرسد كه جنبههاى شناختى كاركردهاى اجرايى از جمله بازدارى باسخ بيشتر توسط مدارهاى از نواحى قشر بيشانى پُشتى جانبى و جنبههاى رفتارى كار كردهاى اجرايى توسط مدارهاى لترال اربيتال

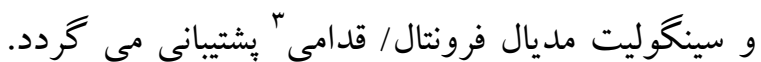
آسيب به هر يكك از اين نواحى مى تواند منجر به صدمات مشابهى بر جنين كاركردهايى گردد (شايو و همكاران، (Y.Y. اغلب موارد آن، دهار آسيب مى گردد كه سببساز نواقصى اساسى در ناتوانى و مشكلات يس از وقوع سكته

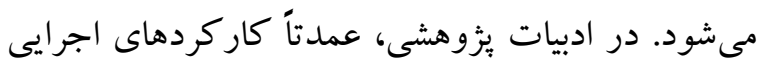

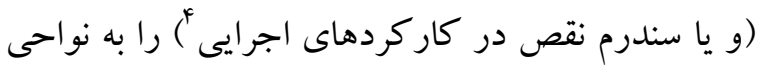
فرونتال مغز نسبت مى دهند كه شمارى از كاركردهاى شناختى را در برمى گيرد؛ با اين وجود، اين كاركردها ممكن است كه در آسيبهاى ساير نواحى مغزى نيز دجار نقص كردند (يارك و همكاران، ها •Y). به نظر مىرسد كه ناحيهى حر كتى اوليه در كاركردهاى اجرايى از جمله بازدارى باسخ افراد نقش مهمى ايفا مىنمايد. شايد بتوان دليل هنين امرى رادر تعاملات كاركردى و عصبى ميان اين نواحى و ناحيه ى بيش بيشانى خلفى جانبى دانست كه در بزّوهش اخير كو كلتا و همكاران (Y) (Y)، مورد توجه قرار كرفت.

\footnotetext{
1. Shao

${ }^{2}$ - Hayes, Donnellan \& Stokee

${ }^{3}$ - Lateral orbital and medial frontal/anterior cingulate circuits

${ }^{4}$ - Dysexecutive syndromes
} 
اين مقاله بخشى از يافتههاى مستخرج از بايانامه

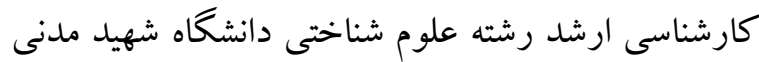
آذربايجان به شماره . است كه توسط معاونت بيزوهشى دانشگاه مورد تصويب قرار گرفته است. بدين وسيله از كليه بيماران و همراهان آنها كه در مراحل اجراى بُزوهش حاضر با سعهصدر نهايت همكارى را با كروه اجرايى تحقيق داشتند، كمال تقدير و تشكر رامىنمايد.

\section{References}

Ditye T, Jacobson L, Walsh V, \& Lavidor M. (2012). Modulating behavioral inhibition by tDCS combined with cognitive training. Experimental brain research, 219 (3), 363-368.

Draaisma LR, Wessela MJ \& Hummel FC. (2020). Non-invasive brain stimulation to enhance cognitive rehabilitation after stroke. Neuroscience Letter,719,133678.

Emsaki G, Molvi H, Chitsaz A, Movahed Abtahi M \& Asghari K. (2011).Psychometric properties of the Montreal Cognitive Assessment (MoCA) in parkinsons disease patients in Isfahan. Journal of Isfahan Medical School, 29 (158), 1391-1400. (In Persian).

Eriksen BA \& Eriksen CW. (1974). Effects of noise letters upon the identification of a target letter in a nonsearch task. Perception \& psychophysics, $16,143-149$.

Floel A, Suttorp W, Kohl O, Kurten J, Lohmann H, Breitenstein C \& Knecht S. (2012). Noninvasive brain stimulation improves objectlocation learning in the elderly. Neurobiology of aging, 33(8), 1682-1689.

Goldstein S \& Naglieri JA. (2013). Handbook of executive functioning. Springer Science \& Business Media.

Gothe N, Pontifex MB, Hillman C \& McAuley E. (2013). The acute effects of yoga on executive function. Journal of physical activity \& health, 10(4):488-95.

\section{نتيجه كيرى}

با توجه به نتايج ياد شده، به نظر مىرسد اعمال تحريك الكتريكى مستقيم فرا جمجمهاى در حين اجراى توانبخشى شناختى به صورت همزمان اثربخشى بيشترى نسبت به اعمال توانبخشى شناختى با استفاده از تكاليف كاميوترى به تنهايى در بازدارى باسخ دارد. تحريك مغزى فرا جمجمهاى مى تواند از طريق فعال ساختن مناطق مرتبط با كار كردهاى اجرايى، زمينه و بستر عصبى مناسبى را براى اعمال بروتكلهاى مختلف توانبخشى شناختى فراهم سازد و اثرات جنين مداخلاتى را با دوام تر سازد. از طرف ديخر، استفاده از تحريك الكتريكى مستقيم فرا جمجمهاى آنودال به صورت دو موضعى همزمان يكك نيمكرهاى مىتواند به دليل تعاملات شبكهاى بين نواحى بـ بـ مختلف مغزى، نسب به روش مرسوم دو الكترودى، اثربخشى تمرينات توانبخشى شناختى را افزايش داده و بهبود عملكرد بيماران دجار سكتهى مغزى را در عملكرد بازدارى افزايش دهد. اعمال تحريك الكتريكى مستقيم فرا جمجمهاى آنودال به صورت دو موضعى همزمان يك بك نيمكرهاى همراه با توانبخشى شناختى با استفاده از تكاليف كامييوترى مىتواند اثربخشى مداخلات توانبخشى انجام شده را افزايش داده و جنين بهبودى را به خارج از جلسات درمانى و يس از مدت زمات

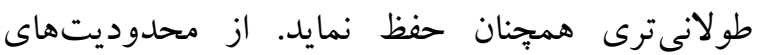
يزؤهش حاضر مىتوان به تعداد كم آزمودنىها در

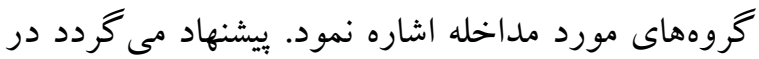
يثزوهشهاى آتى در ابعاد كستردهتر انجام گيرد و كارايى اين بروتكل بر بهبود ساير عملكردهاى شناختى بيماران موردبررسى قرار گيرد. 
Hadianfard H, Najjarian B, Shokr Kon H, \& Mehrabi Zadeh M. (2001). Construction \& validation of the Farsi version of the continuous performance test. Journal of Psychology, 4 (16), 388-404. (In Persian).

Hasanzadeh Pashang S, Zare H, Alipour A, \& SharifAlhoseini M. (2020). The effectiveness of cognitive rehabilitation in improving visual and auditory attention in ischemic stroke patients. Acta Neurologica Belgica, doi: 10.1007/s13760-020-01288-4. In Persian).

Hayes S, Donnellan C, \& Stokee E. (2016). Executive dysfunction and balance function post-stroke: A cross-sectional study. Physiotherapy,102(1), 64-70.

Hollaa B, Biswala J, Ramesha V, Shivakumara V, Bharath RD, Benegala V, Venkatasubramaniana G, Chanda PK, \& Murthy P. (2020). Effect of prefrontal tDCS on resting brain $\mathrm{AMRI}$ graph measures in Alcohol Use Disorders: A randomized, double-blind, sham-controlled study. Progress in Neuropsychopharmacology \& Biological Psychiatry, 102,109950.

Javadi AH, \& Walsh V. (2012). Transcranial direct current stimulation (tDCS) of the left dorsolateral prefrontal cortex modulates declarative memory. Brain stimulation, 5(3), 231-241. (In Persian).

Jeon SY, \& Han SJ. (2012). Improvement of the working memory and naming by transcranial direct current stimulation. Annals of rehabilitation medicine, 36(5), 585-595.

Kukleta M, Damborska A, Roman R, Rektor I, \& Brazdil M. (2016). The primary motor cortex is involved in the control of a non-motor cognitive action. Clinical Neurophysiology, 127(2), 1547-1550.

Kwon YH, \& Kwon JW. (2013). Response inhibition induced in the stop-signal task by transcranial direct current stimulation of the presupplementary motor area and primary sensoriomotor cortex. Journal of physical therapy science, 25(9), 1083-1086.
Li YJ, Liang KK, Zhang L, Pan R, Hu YM, \& Zhao JH. (2020). Remote Ischemic PostConditioning may Improve Post-Stroke Cognitive Impairment: A Pilot Single Center Randomized Controlled Trial. Journal of Stroke and Cerebrovascular Diseases, 29 (11), 105217.

Lindenberg R, Renga V, Zhu L, Nair D, \& Schlaug G. (2010). Bihemispheric brain stimulation facilitates motor recovery in chronic stroke patients. Neurology, 75(24), 2176-2184.

Lipskaya-Velikovsky L, Zeilig G, Weingarden H, Rozental-lluz C, \& Rand D. (2018). Executive functioning and daily living of individuals with chronic stroke: measurement and implications. International Journal of Rehabilitation Research, 41(2), 122-127.

Maizey L, Evans CJ, Muhlert N, Verbruggen F, Chambers CD, \& Allen CPG. (2020). Cortical and subcortical functional specificity associated with response inhibition. NeuroImage, 220, 117110.

Nasreddine ZS, Phillips NA, Bedirian V, Charbonneau S, Whitehead V, Collin I, Cummings JL, \& Chertkow H. (2005). The Montreal Cognitive Assessment, MoCA: a brief screening tool for mild cognitive impairment. Journal of the American Geriatrics Society, 53 (4), 695-699.

Park SH, Koh EJ, Choi HY, \& Ko MH. (2013). A double-blind, sham-controlled, pilot study to assess the effects of the concomitant use of transcranial direct current stimulation with the computer assisted cognitive rehabilitation to the prefrontal cortex on cognitive functions in patients with stroke. Journal of Korean Neurosurgical Society, 54(6), 484488.

Park YH, Jang JW, Park SY, Wang MJ, Lim JS, Baek MJ, Kim BJ, Han MK, Bae HJ, Ahn S, \& Kim SY. (2015). Executive Function as a Strong Predictor of Recovery from Disability in Patients with Acute Stroke: A Preliminary Study. Journal of Stroke and Cerebrovascular Diseases, 24(3), 554-561.

Penolazzi B, Bergamaschi S, Pastore M, Villani D, Sartori G, \& Mondini S. (2014). Transcranial direct current stimulation and cognitive 
training in the rehabilitation of Alzheimer disease: A case study. Neuropsychological Rehabilitation, 25(6):799-817.

Poulin V, Korner-Bitensky N, Dawson DR, \& Bherer L. (2012). Efficacy of Executive Function Interventions After Stroke: A Systematic Review. Top Stroke Rehabilitation,19 (2), 158-171.

Povroznik JM, Ozga JE, Haar CV, \& Engler-Chiurazzi EB. (2018). Executive (dys)Function after Stroke: Special Considerations for Behavioral Pharmacology. Behavioral Pharmacology, 29 (7), 638-653.

Shao K, Wang W, Guo SZ, Dong FM, Yang YM, Zhao ZM, Jia YL, \& Wang JH. (2020). Assessing executive function following the early stage of mild Ischemic stroke with three brief screening tests. Joumal of Stroke and Cerebrovascular Diseases,29 (8), 104960.

Utz KS, Dimova V, Oppenlander K, \& Kerkhoff G. (2010). Electrified minds: transcranial direct current stimulation (tDCS) and galvanic vestibular stimulation (GVS) as methods of non-invasive brain stimulation in neuropsychology - a review of current data and future implications. Neuropsychologia, 48 (10), 2789-2810.

Vaseghi B, Zoghi M, \& Jaberzadeh S. (2015). The effects of anodal-tDCS on corticospinal excitability enhancement and its after-effects: conventional vs. unihemispheric concurrent dual-site stimulation. Frontiers in Human Neuroscience, 9, 533-543. (In Persian).

Veisi-Pirkoohi S, Hassani-Abharian P, Kazemi R, Vaseghi S, Zarrindast MR, \& Nasehi M. (2020). Efficacy of RehaCom cognitive rehabilitation software in activities of daily living, attention and response control in chronic stroke patients. Journal of Clinical Neuroscience, 71, 101-107.(InPersian).

Verbruggen F, Logan GD, \& Stevens MA. (2008). STOP-IT: Windows executable software for the stop-signal paradigm. Behavior research methods, 40(2), 479-483.

Worsching J, Padberg F, Goerigk S, Heinz I, Bauer C, Plewnia C, Hasan A, Ertl-Wagner B, \&
Keeser D. (2018). Testing assumptions on prefrontal transcranial direct current stimulation: Comparison of electrode montages using multimodal fMRI. Brain Stimulation, 11(5), 998-1007.

Yoo Ch, Yong MH, Chung J, \& Yang Y. (2015). Effect of computerized cognitive rehabilitation program on cognitive function and activities of living in stroke patients. Journal of physical therapy science, 27(8), 2487-2489. 